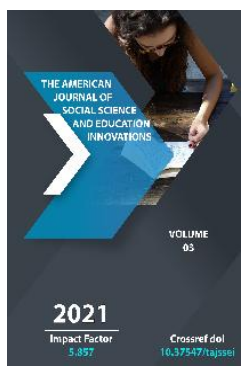

\title{
Abdullah Avloni's Pedagogical Views And Its Essence
}

\author{
Dilfuza Usmonovna Azimova \\ Lecturer Of Termez State University, Uzbekistan
}

Journal Website:

http://theamericanjour

nals.com/index.php/taj

ssei

Copyright: Original content from this work may be used under the terms of the creative commons attributes - $1: \ldots . . .-$.

\section{ABSTRACT}

This article highlights about Abdullah Avloni who paid special attention to the unity of education and upbringing. It is only through the education of thought, which is an expression of human mental activity, that great honor and perfection are attained, and in this case the teacher's the breadth of the field of thinking, the high level of knowledge in all respects It is crucial in the education of students.

\section{KEYWORDS}

Category, classical literature, humorous spirit, social content, social content, enlightenment, "education", "science", "science", children's literature, pedagogy.

In the development of society, pedagogical views today play an important role in the creation of the Uzbek national school. There is 
a growing interest in the in-depth study of Avloni's creative heritage. He divided human behavior into good and bad. In the first part, entitled "Good Behaviors", he describes 31 virtues, and in the second part, called "Bad Behaviors", he describes 20 virtues. To substantiate his views, he cites verses from the Qur'an and hadiths, as well as the opinions of famous thinkers such as Aristotle, Socrates, Ibn Sina, Saadi, Mirza Bedil. After expressing his attitude to each moral category, he adds a byte or a proverb that expresses the content of that thought. Based on the views of the "moral scholar", Avloni divides people's behavior into good and bad behaviors, based on their self-discipline. He considers such virtues as anger, lust, ignorance, and depravity as signs of bad behavior, while he attributes such virtues as virtue, gentleness, courage, discipline, conscience, and love of country.

\section{MATERIALS AND METHODS}

Avloni's first poems, which sang the ideas of the Enlightenment and the national revival, will always be an invaluable asset of Uzbek national Renaissance literature In his poems of this category, he enriched the poetic forms of Uzbek classical literature with great social content, enlightenment ideas, humorous spirit and folk melodies. Abdullah Avloni also wrote a number of poems and parables for children. In these works, the poet aims to expand the horizons of school-age children, to instill in them a love for school and books, labor, nature and the Motherland. At the heart of many of his poems is the idea of loving the Motherland. In these poems, the poet describes the Motherland in simple and sincere verses, which can be enjoyed not only in the middle of those 10 years, but also by today's school-age children. In fact, the poet began the description of the Motherland, saying: achieve arousal of kindness. Enlightenment and the social theme occupy a central place in Avloni's poetry.

The poet sings with pleasure the virtues of science. Concepts such as "school", "education", "science", "science" in the poems of the poet rise to the level of a symbol of goodness, and "ignorance" and "ignorance" are interpreted as a symbol of darkness and evil. . There is also a work by Abdullah Avloni, "A Brief History of the Prophet and the History of Islam." This work is intended for primary school students. This work was first published by Munavvarqori in 1910 at II Publishing House in Tashkent. During the years of independence, Zokirkhon Afzalov was published by Shokirhon ogli in 1994 in the "Fan" publishing house. The treatise mentions the stories of the prophets from Adam to Muhammad and the appearance of Islam. In the history of Islam, the history of the prophets, the lives of the Prophet Muhammad and the history of Islam, as well as the history of the first caliphate are studied in three stages. Nasiruddin Rabguzi's "Qissai Rabguzi", Alisher Navoi's "Tarihi anbiyo va hukamo" are related to the history of the prophets, Alikhantora Soguni's "Tarihi Muhammadiy" is the second and Rizoud-din ibn Fakhrud-din's " Khulafoi Rashidin "covers the third period. Abdullah Avloni's work combines these three periods. The main goal of the writer was to acquaint children, who are the future of the nation, with the history of Islam, to raise religious awareness, to instill in their hearts the light of faith. This work of Abdullah Avloni is commendable. Along with the culture and enlightenment of the Uzbek people, he played 
an important role in the socio-political life of the neighboring Afghan people in 1919-1920. He served as the Soviet government's political representative and consul in Afghanistan. In addition to writing, Abdullah Avloni was involved in opening schools, educating the people, educating Uzbek women, and training teachers and intellectuals. will be used. From 1923 to 1924 she was the director of women's and men's educational institutions in the old city, from 1924 to 1929 she was a teacher at the Tashkent Military School, from 1925 to 1924 at the Central Asian Communist University, the Central Asian School of Agriculture. He teaches at the Central Asian State University. He worked as a professor and head of the department of language and literature of the pedagogical faculty. In 1933, he compiled and published the "Literary Chromatology" for the 7th grade of Uzbek schools. Nicknames of Abdulla Avloni "Hijran", "Nabil", "Indamas", "Shuhrat", "Tang-riquli", "Surayyo", "Shapaloq", "Chol", "Ab", "Chigaboy", "Abdulhaq" $\mathrm{He}$ is the author of more than 4,000 poems. Avloni was awarded the title of "Hero of Labor" in 1927. In 1930 he was awarded the honorary title of "Zarbdori of public education of Uzbekistan." At present, there are a number of schools named after Abdulla Avloni in independent Uzbekistan.

The Writers' Union of Uzbekistan has established an award for children's literature in his name. One of the streets of Tashkent, the Republican Center for Teacher Training and one of the mahallas are named after him. The Abdulla Avloni Museum has been established at the Republican Center for Teacher Training. The upbringing of children is not a personal matter, it is a great social work of state and social significance, it is such a great work, both the future of the Motherland and the destiny of the nation are connected with upbringing. In the words of Avloni, "... education is for us a matter of life or death, salvation or destruction, happiness or disaster." A. Avldoni pays special attention to the unity of education and upbringing. It is only through the education of thought, which is the expression of human mental activity, that great honor and perfection are attained, and in this case the teacher's the breadth of the field of thinking, the high level of knowledge in all respects plays a crucial role in the education of students. The ability to think Development leads to rational behavior: it teaches students to distinguish between good and bad behavior, to acquire the good qualities necessary for a perfect person, to stay away from bad habits that lead a person astray.

In the chapter "Good manners" of Abdullah Avloni's work, there is perseverance, religion, Islam, control, zeal, obedience, contentment, courage, knowledge, patience, discipline, scale of desire, conscience, love of country, honesty, vision, chastity, modesty, understanding and thinks in detail about intellect, wisdom, economics, dignity, danger and prosperity, obedience, truthfulness, benevolence, munism, devotion, love, forgiveness, examples from the verses of the Qur'an, hadiths to prove his point, great thinkers He quotes Plato, Aristotle, Socrates, Baqrat, Ibn Sina, Mawlana Rumi, Sheikh Sa'di, Mirza Bedil. Representatives of the Jadid movement, like the enlighteners of Western Europe, raised the banner of science and modern development. The fanatical scholars and the ancients struggled to keep up. It should not be forgotten that the main difference between the Uzbek enlighteners 
and the European enlighteners was that their activity was based on the idea of liberation of the nation from colonial oppression, the idea of independence. In the pedagogical views of Abdullah Avloni, the high glorification of the mind and science is inextricably linked with the glorification of man. Because Allah created man greater than all other creatures. He gave him Mind for such a great purpose as the attainment of the happiness of the two worlds. With the help of this Mind, man acquires knowledge, progress, and rules the world. Here is A. Avloni's description of the mind: "The mind is the perfect, the only guide of human beings ... Our Master Rasûlullah (sall-Allâhu 'alaihi wa sallam) said: "O people! Humble your mind. When Abdullah Avloni thinks about human health, it is the main one One of the factors is a separate chapter on cleanliness. Known as 'Nazofati' It is a means of making a person beloved among the people, even in the sight of Allah purity is delicacy. One should keep not only one's body and clothes clean, but also one's place of residence, environment and city. Environmental pollution is the cause of various diseases. It is unfortunate that the colonial authorities in and around Avloni did not even think about the well-being of the country and the health of the population, but only about the part of the cities inhabited by the colonialists. A well-known Tatar enlightener and writer, Abdurashid Qazi Ibragimov (of Uzbek descent), who traveled to Turkestan in late 1907, exposed Tsarist Russia's horrific colonial policy in Turkestan: , flat houses, electric light walks are an example of Europe. But Muslim Tashkent is the opposite. In the first spring, at the end of spring, it is impossible to walk through the houses in the city. It cannot be described even in words ... although the city is a city,
Tashkent, the office, the income is the same, the main part of the population is Muslim. Although a little, he has a primitive understanding of the Russian language and the exact sciences It was possible to study only in Russian-style schools, but it was Abdurashid Qazi Ibrahimov, who traveled to Turkestan in 1907, pays special attention to this issue. In this way, A. Avloni expresses his profound thoughts about such human qualities as patience, humility, scale, selfdiscipline, and conscience. But his views on the homeland are more important, more significant. The homeland is as single as the Mother, as sacred as the Mother. This topic has attracted the attention of many literary and artistic figures.

It should be noted that in the early 1970s, Erkin Vahidov's poems "O'zbegim" and Abdulla Aripov's "Uzbekistan" resonated among the Uzbek people to such an extent that they even shocked Soviet ideologues. The issue of teaching the mother tongue as a basis for the national education of the Jadids They intensified the attention, because the national spirit, the national spirituality entered with milk ..." as they said, could only be absorbed through the mother tongue. In general, these were the essence of the pedagogical views of modern thinkers. No special attention was paid to the teaching of the Muslim language, religion and history in state-run Russianlanguage schools for indigenous children. The first and decisive stage of the Russification policy was the upbringing of junior officials who did not know their language, religion, spirituality and history. Mahmudkhoja Behbudi, Munavvarqori Abdarashidkhon oglu, Abdurauf Fitrat, Abdulla Avloni's "usul jadid" schools, which were opened and gained great 
popularity among the people, were essentially directed against the Russian-style schools.

\section{CONCLUSION}

Abdullah Avloni is a well-known journalist, public a figure, a poet, a playwright, a writer, a translator, and a great enlightened teacher. SHE IS enlightenment, enlightenment and during his short life, creating in a very difficult, turbulent period works on a wide range of cultural issues, which can be divided into several volumes wrote. He is tireless in expanding the spiritual world of the next generation with care, "Literature or National Poems," "Turkish Gulistan, or." "Ethics", "Ustodi avval", "Muallimi soniy" and other textbooks and manuals, as well as the promotion of performing arts in Turkestan. , Created dramatic plays such as "Two Loves", "Portuguese Revolution".

\section{REFERENCES}

1. Karimov I.A. Independence and $\mathrm{m}$ a 'naviyat. - Tashkent, o 'Uzbekistan, 1994.

2. Rayimovich, Abdukayumov Asror. "EARLY SETTLEMENTS OF CENTRAL ASIA AS A FACTOR OF FORMATION OF FIRST SOCIETIES (ON EXAMPLE OF THE SETTLEMENT OF SARAZM)." European science review 5-6 (2020).

3. Isayev, O. (2019). THE CULTURAL LIFE IN SURKHAN OASIS: INFORMING OF ACHIEVEMENTS AND PROBLEMS BASED ON ARCHIVAL MATERIALS (1925-1941 YEARS). The Light of Islam, 2019(4),

4. Tursunov I., Nishonaliev U. Pedagogical course. - T, o 'kytuvchi, 1997.

5. Yusupov E. The moral foundations of human perfection. - T .: Universitet, 1998.
6. Mirziyoev Sh.M. We will build our great future together with our brave and noble people // - Tashkent: NMIU "Uzbekistan", 2017. Pages 301-302

7. Buronov A. K. Uzbekistan In The New Era Of Trade Union Development (2016-2020) //The American Journal of Social Science and Education Innovations. - 2021. - T. 3. - №. 01. - C. 294-297

8. Allamuratov Shukhrat Ashurovich. CRAFT AND TRADE RELATIONS IN EASTERN BEKS OF THE BUKHARA EMIRATE. ACADEMICIA: An International Multidisciplinary Research Journal. Vol. 11, Issue 2, February 2021.

9. Allamuratov S.A. The role of the Amudarya waterway in cultural-religious relations of the peoples of Central Asia. //Ўтмишга назар журнали. - 2019. - Т. 24. - №. 2. pp. 23-29

10. Kushakov, S., \& Akhmedov, S. (2021). The Ethnic History And Composition Of Uzbek People: On The Example Of Two Languages, Settlement And Livestock Tribes. The American Journal of Interdisciplinary Innovations and Research, 3(02), 24-27.

11. Abdulloev, S. B. (2021). Positive Attitudes To" Dev" In Central Asian People. The American Journal of Social Science and Education Innovations, 3(01), 275-279.

12. Yusupovich, K. S. (2020). The Emergence Of Religious Views Is Exemplified By The Southern Regions. The American Journal of Social Science and Education Innovations, 2(10), 143-145.

13. Uktamovna, Y. D. (2020). The Effect Of The Russian Empire On The Political Life Of The Emirate Of Bukhara (1868-1917). The American Journal of Social Science and Education Innovations, 2(10), 171-177 
14. Orziev, Makhmud Zaynievich, and Amonkeldi Khasanovich Akhmatov. "THE CHANNEL FROM SIRDARYA TO BUKHARA: TRUTH OR FRAUD." Scientific reports of Bukhara State University 3.1 (2020): 234-239.

15. Orziev, Mahmud Zaynievich. "THE SECOND WORLD WAR AND THE UNOPENED AFGHAN FRONT." Scientific reports of Bukhara State University 4.3 (2020): 243-249.

16. Bakiev, Anvar, and Zubayda Yuldasheva. "THE FIFTH CIVILIZATION OF THE ANCIENT EAST." Theoretical \& Applied Science 8 (2020): 39-45.

17. Ikromov, N. M. IS BACTRIA THE KINGDOM OR THE KAVIAN?. EPRA International Journal of Multidisciplinary Research (IJMR).Journal of Multidisciplinary Research (IJMR).

18. Tursunov SN, and others. Excerpts from the history of Sherabad - Tashkent: New edition, 2014. $-56 \mathrm{p}$.

19. Imamov.T. The market economy requires a new way of working. Lenin's Flag, June 28, 1991, p.

20. Orziyev, Mahmud Zayniyevich, and Bakhshand Bakhodirovna Yunusova. "Difficult ways edifying education." European Conference on Education and Applied Psychology. 2014. 